\title{
PERFORMANCE STUDY AND EVALUATION OF A SOLAR PV TESTBED SYSTEM USING LabVIEW
}

\author{
A. FAROOQ ${ }^{1, *}$, R. $A F T A B^{2}$ \\ ${ }^{1}$ Bright Trading \& Contracting Co., Ltd., Makkah, Kingdom of Saudi Arabia \\ ${ }^{2}$ Federal Urdu University of Arts, Science \& Technology, Islamabad, Pakistan \\ *E-mail: aqeelfarooq92@gmail.com
}

\begin{abstract}
The world is running out of the oil and natural resources with each passing day. Most of the electricity around the world is generated using natural resources. E-governments are trying to move the electricity production from natural resources to hydro and solar generation. For the places such as in the Middle East and deserted areas in Sindh district of Pakistan, where water resources are low and solar is superlative for generating electrical energy. The objective of this research is to implement, model, design and simulate the Photovoltaic Solar Monitoring (PVSM) systems. The simulation for the system is implemented on LabVIEW software and tests are carried out for certain values of input. All the details, expected outcomes, problems, and results are part of this research.

The scope of this research is to obtain the results using real-time simulations performed in LabVIEW. The simulation performed in LabVIEW mimics the implementation of the advanced automation and control system technique Supervisory control and data acquisition (SCADA). The objective of this research work is to perform the essential simulation that is required to investigate current products for PV factors monitoring that influence solar panels efficiency. The goals are: to design and to develop a system for monitoring the PV solar systems using LabVIEW, to simulate the performance of PV solar system using the theoretical methods, to monitor system by means of LabVIEW and to show theoretical effects in the method of the curve of PV performance parameters. Implementing the interfacing technique at home level to monitor the local solar parameters helps in utilizing the solar generated energy in an efficient way. Analysis in LabVIEW helps in studying the parametric condition of the environment where solar is required to be installed.
\end{abstract}

Keywords: photovoltaic, monitoring, LabVIEW, automation, electrical energy, SCADA

\section{Introduction}

For the deserted area such as Middle East and Sindh district of Pakistan, the sunlight intensity in the day is very high and sunlight can be used to generate electrical energy using solar panels. Solar energy has proved itself quite useful in the recent years and there are no side effects of generating from solar system [1]. Moreover, the suburban trend for gaining the energy is shifting towards seeking energy from sunlight because all other energy generating plants (i.e., Coal Power Plant, Fossil Fuel Power Plant, etc.) rely on the principle of converting energy from mechanical, chemical and thermal into electrical energy. In contrast to the solar converted power, which requires no mechanical energy provision mechanism and is based solely on getting en- ergy from sunlight. Unlike in wind generation system or hydropower generators working as turbines where turbines come in motion due to the flow of water. In case of solar generation, the power comes directly in the form of sunlight, whereas in all other cases, the generating system and prime mover must be designed but in case of solar power system, the prime mover is not required to be designed as sunlight is a natural phenomenon [2]. With the sunlight as the source of input, it is only required to design the system and not the prime mover, only the intermediate system is required to be designed whereas the input is natural process (sunlight) as it comes directly from the sunlight. The input can be maximized by using a maximum power point solar tracker. A structural model approach for this is being discussed by Pathania et al. [3].

This is an open-access article distributed under the terms of the Creative Commons Attribution-NonCommercial 4.0 International License (https://creativecommons.org/licenses/by-nc/4.0/), which permits unrestricted use, distribution, and reproduction in any medium for non-commercial purposes, provided the original author and source are credited, a link to the CC License is provided, and changes - if any - are indicated. 
Solar cells are used these days to generate electrical energy directly from sunlight. Solar panels are also installed on large grid system to produce and provide the essential quantity of electrical energy to the system [4]. In some of systems, these solar cell systems act as the backup source of power. Most of the users favor to install solar panel at their home because in case of solar panel, the initial cost is high while there is only a little or no maintenance cost.

In Micro grid systems [5], different power sources relate to the grid station to maintain the steady flow of the electricity and the solar cells are connected to each other in series or parallel to obtain large solar system to high power Loads. Prior to installing the solar cell at specific place, it is necessary to perform certain set of tests and analysis that helps in increasing the energy efficiency.

In this research work, the solar cell simulation has been done using LabVIEW [6] program to obtain the Open circuit voltage (OCV), Daily Load (DL), Short Circuit Current (SCC) and other factors. These factors help in the placement of solar cells as well. The computer program implemented in LabVIEW [7] is an interactive computer-based [8] program that helps in performing the solar cell analysis and obtaining useful results from it. The implemented LabVIEW program is an automated computer program that inputs temperature (IT), Volts (V), Number of Panels (NP), Irradiance (Ir) and outputs the Performance parameters, Power Parameters, Cost of the system, Annual energy value, daily energy value, solar generated power and solar generated daily power curve as well. All these data can be helpful in designing and installing the solar panel system at specific locations. The environmental parameters help in the performance of the generated solar energy [9]. The technique of SCADA allows the supervisory control of the plant [10].

The aim and goal of this research work is to implement the PV monitoring system that investigates and finds the factors needed to describe the complete behavior of the solar cell. The main objective is to make the designing simple. One such example of traffic system in smart cities using LabVIEW has been discussed by Farooq et al. in their paper [11]. The goal here is to study the $\mathrm{V}-\mathrm{I}$ characteristics curve using LabVIEW and implement the complete system in LabVIEW so that a Graphical interface screen can only be used to obtain results. The other primary purposes are to display theoretical curves for energy and power as well. Displaying all the performance parameters, power parameters is also one of the secondary goals of this project. The project purpose is to create the solar cell-based simulation [12] system in LabVIEW that can do efficient calculation and obtain the system performance. In this way by performing the simulation, efficient system can be designed. One of the main purposes of the project is to introduce the solar based simulation in LabVIEW [13] and use some simulating software to obtain the desired quantities.

\section{Literature review}

An electric cell is a chemical cell that generates electricity [14]. Typically, the electric cell produces electrical energy from the chemical energy and a lot of such electric cells are available commercially. Chemical energy is internal energy of the body and chemical cells produce electrical energy from this internal energy. This is the principal behind the working of chemical cells. This paper contains a discussion about the solar cells. Solar cells are alternatively pronounced as the Photovoltaic (PV) cells. A characteristic solar cell yields less than 3 Watts at $0.5 \mathrm{Vdc}$ [15]. To run the higher power load, a number of solar cells are connected in series or in parallel to create a high power source [16]. Solar cells are joined with each other to form an array named as PV array [17]. PV arrays produce power only when sun light falls on them. Photovoltaic systems usually use a method to store energy so the energy from the sunlight is stored in batteries and will be used later. Normally, the storage batteries are of rechargeable Lithium-polymer or Nickel-cadmium batteries, but efficient and more exotic methods can be used for this purpose as well. In toting to energy storage, storage batteries also deliver sub transient, transient and steady state suppression, system voltage regulation, efficiency increment and a constant current source that can rise PV array working capabilities [18].

When a battery charge storing system is used, then it is imperative to add micro-controller circuit in to the system to provide efficient switching, so the batteries can be made to prevent from getting either of the overcharging and discharging conditions that reduce battery life and system performance [19]. Maintaining the battery performance is very important for improving the life of the system. To monitor the battery life and usage over time, sensors and some monitoring devices are paired and installed in the system, so that the usage of the battery can be improved [20]. It is the requirement for most of the users that all of the Loads whether AC or DC have to serve. For these requirements, a DC-to-AC inverter will be used to convert the DC voltage from the PV system to AC Voltage [21]. If the complete system contains a backup system, then in case of failure, no disconnection occurs but still most of the times, it is required that the system must contain the micro-controller circuit to switch between auxiliary and back up supply.

It is also likely that PV systems are being connected in micro grid system. Such systems may supply extra PV energy to the network or use the network as 


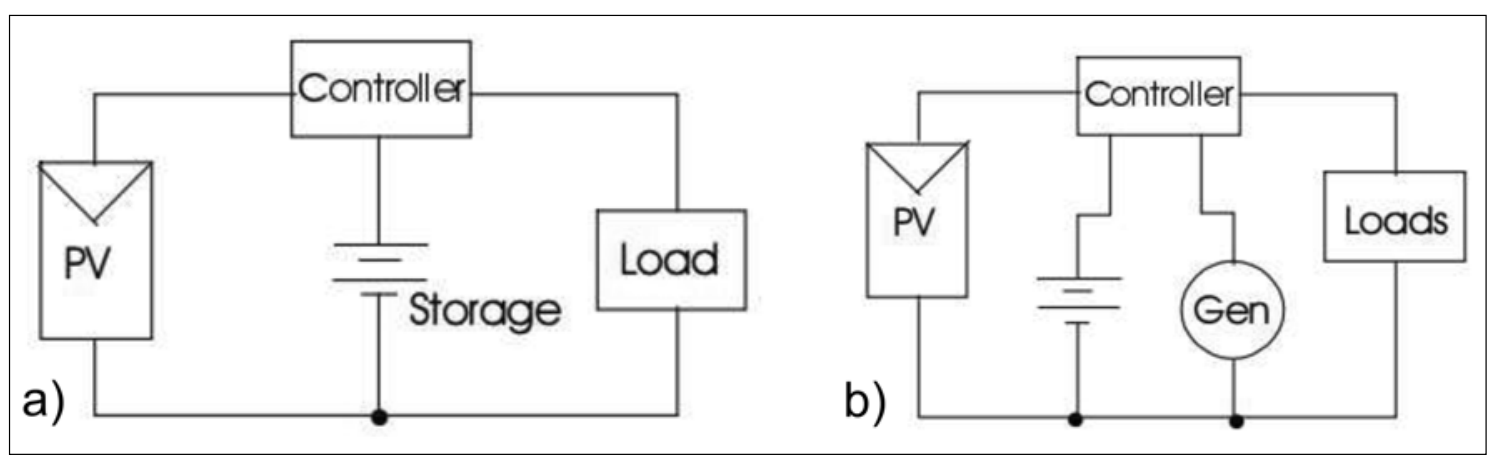

Fig. 1. PV-cell configurations. (a) PV-cell with controller and load, (b) PV-cell with backup generator connected

a backup system in situations of inadequate PV generation [22]. These microgrid (with PV connected) organized systems need to include proper switching circuitry so the PV system will be removed from the grid when failure occurs.

Figure 1a shows the case when the PV-cell array is connected to controller and the load with excess power being stored in the storage battery so that it will be used at night [23]. Figure 1a can be modified to create Fig. 1b by including the backup generator in parallel to the battery so that the battery system failure condition can be prevented [24]. When sunlight falls on PV-cell, electron-hole pair is generated by the contact of the incident photons on atoms cell. The electric field twisted by the PV-cell junction sources the electron-hole generated by photons braces to isolate, with the electrons traveling into the n-region of the atom and the holes drifting into the p-region of the atom [24]. Since PV-cell produces DC power so it is necessary to convert that DC power to the AC power so that we can get the varying voltage waveform that can run any kind of signal. The amount of $I$ and $V$ available from the cell depends upon the sunlight fall on the PV-cell [25].

\section{Analysis}

The greater the light falls, the larger will be the solar irradiance and the more will be the corresponding voltage.

$$
I=I_{l}-I_{0}(\exp \{q V / k T\}-1),
$$

where $I_{l}$ is the component of cell current due to photons, $q=1.6 \cdot 10^{-19}$ coulomb, $k=1.38 \cdot 10^{-23} \mathrm{~J} / \mathrm{K}$ and $T$ is the temperature in $\mathrm{K}$ (Kelvin). Both voltage and current generated by $\mathrm{PV}$-cell are limited. To regulate the short circuit current of a PV-cell, merely set $V=0$ in the backer. This leads to $I_{S C}=I$.

The open circuit voltage obtained from the solar cell and the current that flows through the solar cell is set to be equal to zero, which yields the below value of the open circuit voltage

$$
V_{o c}=\frac{k T}{q} \ln \frac{I_{l}+I_{0}}{I_{0}} .
$$

The dot product of voltage and current in the solar cell gives the PV-cell or solar cell power. Solar power can be defined as:

$$
\begin{array}{r}
\text { Solar power }=\frac{0.24(\text { Sun brightness })}{200} \\
\times(\text { No. of panels }) \times(\text { Signal } / 2),
\end{array}
$$

where

$$
\text { Signal }=A \cdot r \cdot P R,
$$

$A=$ area of solar panel, $r=$ solar yield $(\%), P R=$ performance ratio.

The maximum power point on PV-cell IV characteristics is exposed in Fig. 2.

If $I_{m}$ represents the current that passes through the solar cell at maximum power, and if $V_{m}$ represents the $V$ at maximum power point obtained, then the cell maximum power can be expressed as

$$
P_{\max }=I_{m} V_{m}=F F \cdot I_{s c} \cdot V_{o c}
$$

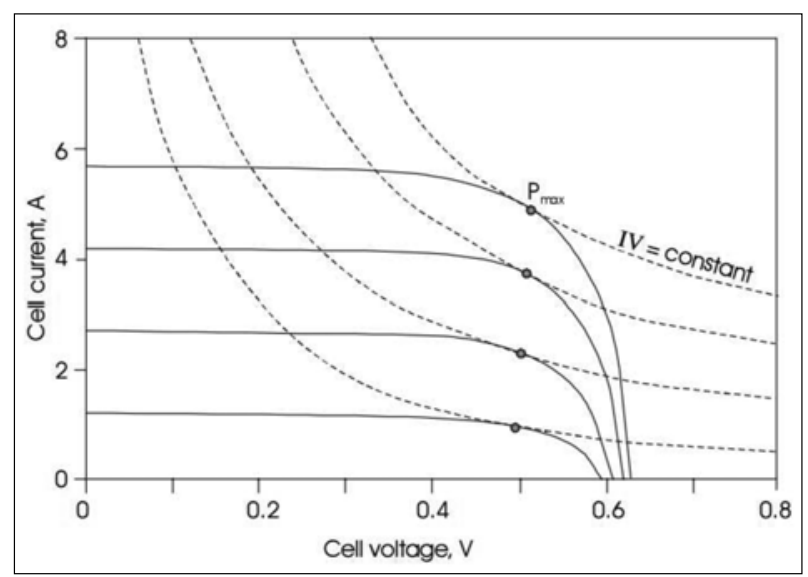

Fig. 2. Maximum power point representation 
where FF is the PV-cell fill factor. The fill factor is associated with the internal manufacturing quality of the cell. Cells with large interior resistance contain smaller fill factors, while the ideal cell keeps a fill factor of unity. It must be kept in mind that a unity fill factor submits a quadrangular solar cell VI characteristic. This situation predicts that the cell functions working as an ideal source. Even though an actual cell does not keep a four-sided characteristic, instead it has an area where its procedure approaches that of perfect $\mathrm{V}$ source and additional area where its process methods that of a lossless source. Loss mostly occurs due to the presence of harmonics. [26].

It is substantial to note that when sunlight falls on PV-cell, it will normally change less than $20 \%$ of the total available sunlight into useful electrical electricity. The remaining of the $80 \%$ irradiance is transformed into heat concluded into the resultant hotness of the cell [27]. As a result, the solar cell can be anticipated to activate overhead normal operating temperature conditions. If the cell is a measure of an engaged system, it will produce more heat then, resulting in an additional absolute temperature performance degradation of solar cell. The photocurrent advanced in a solar cell is reliant on the amount of the light event originally on the PV-cell. The current flow through the solar cell is also highly dependent on the wavelength of the available instance light [28].

The integral of the power generated using the solar cell can be named as solar energy. Mathematically it can be written as:

$$
\text { Solar energy }=\int(\text { Solar power }) \mathrm{d} t \text {, }
$$

whereas the daily energy value is the average value of the energy used over the one complete day.

\section{Daily energy $=$ Average of (Energy signal array)}

When the daily energy is multiplied by 365 , it produces the annual or yearly value of the energy:

$$
\text { Annual value }=365 \cdot(\text { Daily energy })
$$

The yield (production) to profit ratio can be written as the ratio of the annual yield to the yearly cost.

$$
\text { Yield to profit }=(\text { Annual yield }) /(\text { Cost }) \text {. }
$$

A single solar cell alone cannot produce large voltage and large current output, so to obtain large current and voltage, it is required to connect them as a combination (series or parallel), so that they produce large current and voltage. This type of connection of more than one cell is called solar array. At night, when we do not have large solar photocurrent, it is required to connect in series combination so that the requirement can be fulfilled. Large numbers of solar cells are connected to each other to form solar array. Solar cells can be connected in series and in parallel as well to form the large array. A PV array is formed as one solar cell is not enough to provide large power. So, to draw large current solar cells, more than one cell is required to be connected in parallel whereas for voltage we connect them in series. In general, solar cells are connected in series and in parallel as well to form the large array. Sometimes the diode is used in blocking mode [29]. In blocking mode, the diode is connected in series to avoid or neglect the flow of current. One of the factors that determines the cell characteristics is the nominal operating cell Temperature (NOCT) [30]. The NOCT is the temperature at which the cell operates at STP condition. STP stands for standard temperature and pressure conditions. The ambient temperature can be linearly approximated by the formula given below.

$$
T_{C}=T_{A}+[(\mathrm{NOCT}-20) / 0.8] \cdot G .
$$

The irradiance and temperature are of considerable importance for the cell performance. The cell performance largely depends on them [31]. Fill factor $(F F)$ is the unit less quantity that is related to the amount of max generated power [32]. Fill factor can be defined as the ratio of maximum power $(\mathrm{mp})$ to the product of open circuit voltage and the short circuit current. Mathematically, it can be defined as:

$$
F F=\left(J_{m p} \cdot V_{m p}\right) /\left(J_{S C} \cdot V_{o c}\right) .
$$

The mathematical behavior and the physics of the solar cell are similar to that of the ideal diode. So, while deriving mathematical formulas, solar cells can be assumed as the ideal diode. Using this assumption, the fill factor can be expressed as:

$$
F F=\left[V_{o c}-\ln \left(V_{o c}+0.72\right)\right] /\left(V_{o c}+1\right)
$$

The practical behavior of solar cells is not in accordance with the Boltzmann approximation. The non-ideal behavior can be better explained by ideality factor $n$ into the Boltzmann equation. The ideality factor determines how ideal the behavior is. The Boltzmann factor can be written as:

$$
\exp \left\{\left(e V_{a}\right) /(n k T)\right\}
$$

The ideality determines the junction joint point quality and the type of recombination used in the solar cell. Ideally $n$ is equal to 1 : it shows the true condition which shows the recombination by the minority charge carriers in the quasi neutral region [33]. There is a type of recombination that occurs when $n$ is equal to 2 . The 


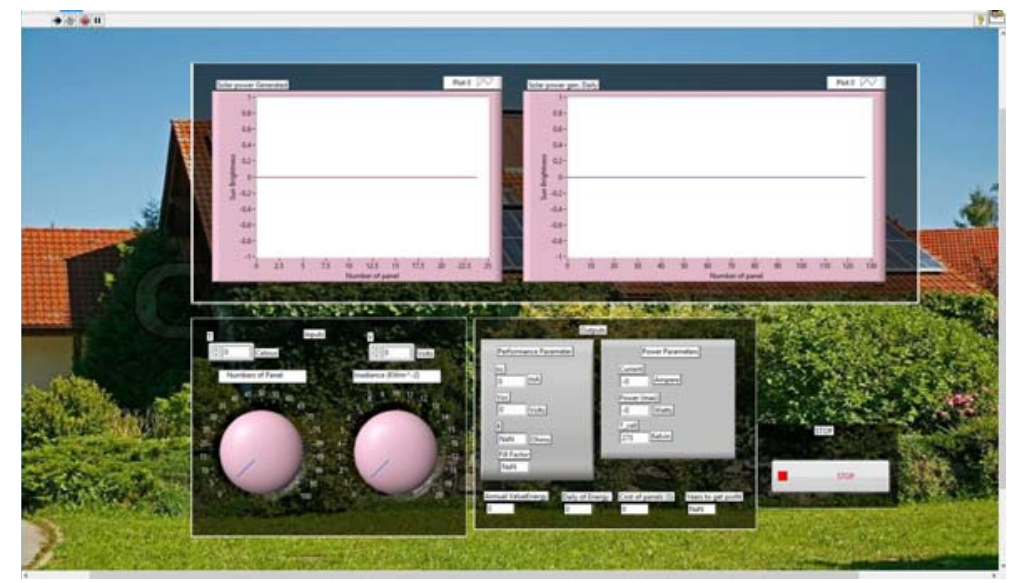

Fig. 3. Front panel view of the project

higher the $n$ value is, the lower will be the form factor. The FF is actual and real-life circuit is low due to the parasitic internal resistance based losses [34].

LabVIEW [35] is a powerful monitoring tool that can monitor the hardware data, process and give the required output results. Software data can be processed in LabVIEW as well. In this project, to implement the complete system equations in the form of VI, LabVIEW has been used. LabVIEW is used since it provides functionality to the functions, structures, palettes, subVI's for building the large system. The below steps can be followed to start the LabVIEW VI program.

1) Open LabVIEW.

2) Then from the Toolbar, go to File $>$ New VI.

3) After that by right clicking on the VI background, components and packages can be selected, placed and connected on the background.

\section{Methodology}

The photovoltaic (PV) monitoring system has been implemented in LabVIEW. Complete sets of equations describing the system have been programmed to run LabVIEW. In LabVIEW, there are two panels. One is front panel and other is block diagram panel [36]. The solar project front panel in LabVIEW is shown in Fig. 3.

Figure 4 represents the block diagram panel of the project. The block diagram panel can be referred as the programming diagram panel. In this panel, graphical programming like one that is done PLC [37] is programmed here and the programming done here is related to the equations that describe the system's behavior.

To run the program, the user needs to run the play button from the top and when the program is required

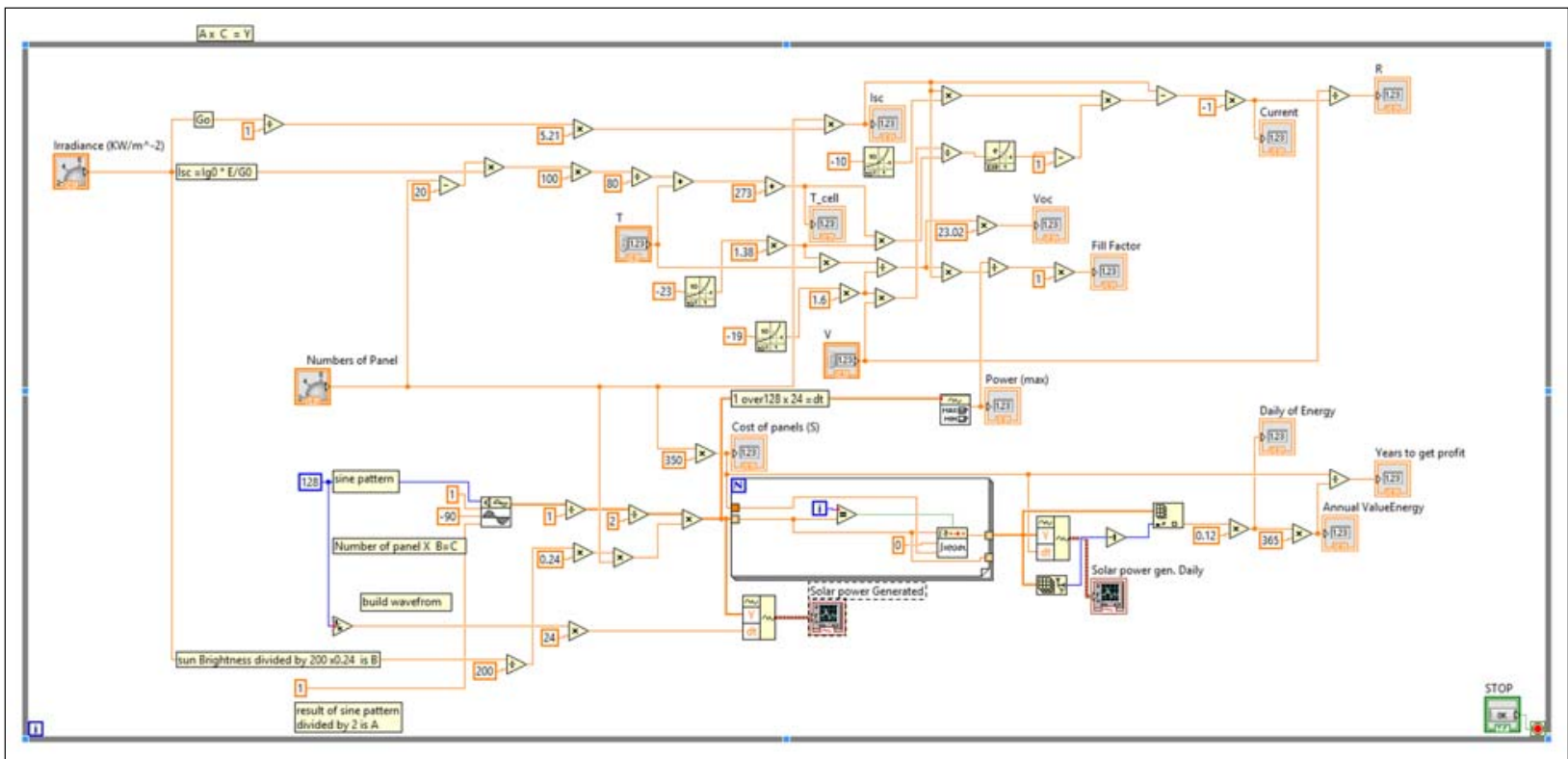

Fig. 4. Block diagram panel for PV monitoring system 
Fig. 5. Toolbar in LabVIEW

to stop, then it can be stopped by pressing the pause or STOP button using the bar shown in Fig. 9 .

To obtain the results, the user needs to enter the inputs in the input section of the Front panel diagram. The input section takes the input values and the output result will be displayed accordingly in the output sections. The output section consists of two parts. One part contains graphical section and other part con- tains output result sections. The output result section displays results in the form of output numbers while the output graph section displays results in the form of graph. The input section of the program has been shown in Fig. 6.

The output panel of the LabVIEW is shown in Fig. 7. The output panel shows the results of the PV program. The program works by taking the inputs, and

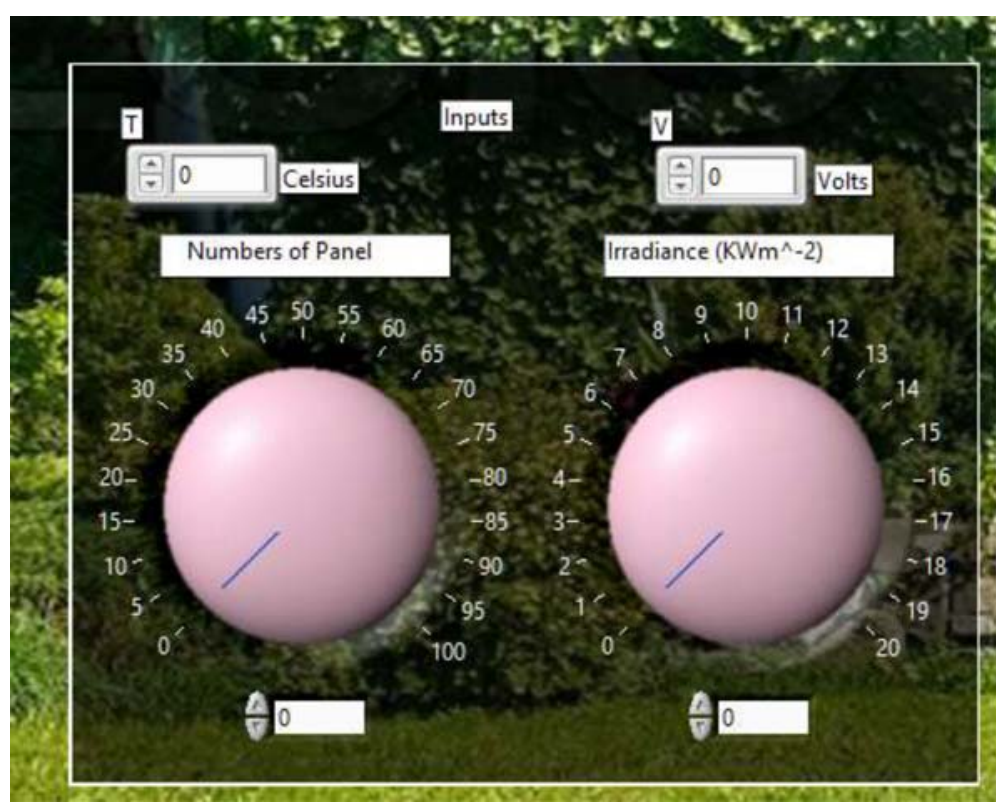

Fig. 6. Input section of the LabVIEW front panel

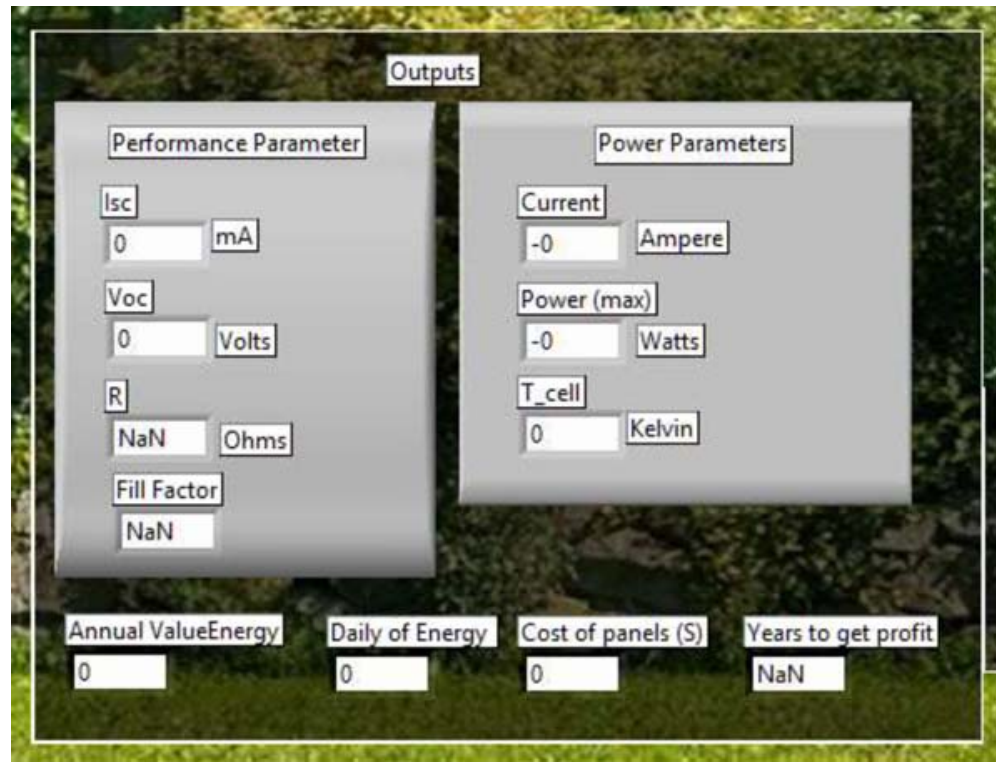

Fig. 7. Output section of LabVIEW front panel 


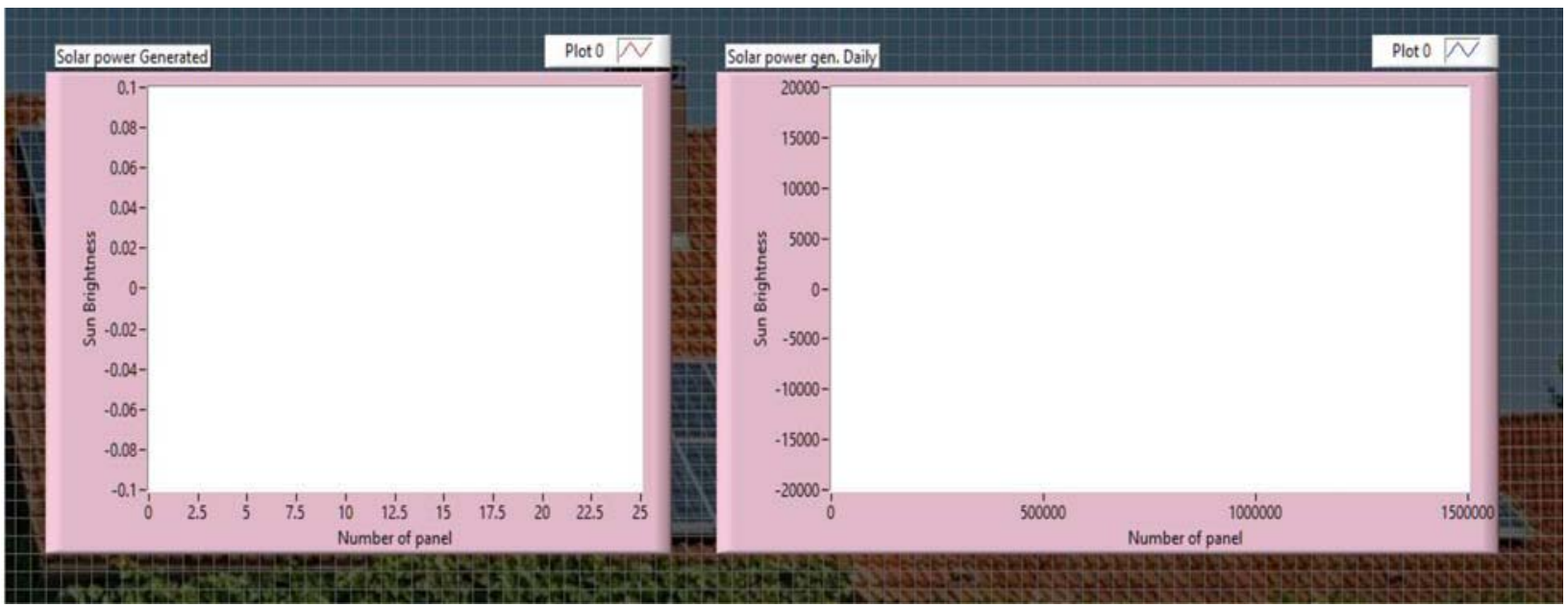

Fig. 8. Graphical section of LabVIEW front panel

then processes the data using applied equations and gives the output results.

The front panel output graphs section is shown in Fig. 8. The graphical section displays the results in the form of graph. The graph consists of solar power generated vs number of panel. The other graph on the left side displays the solar generated daily power vs the number of panels.

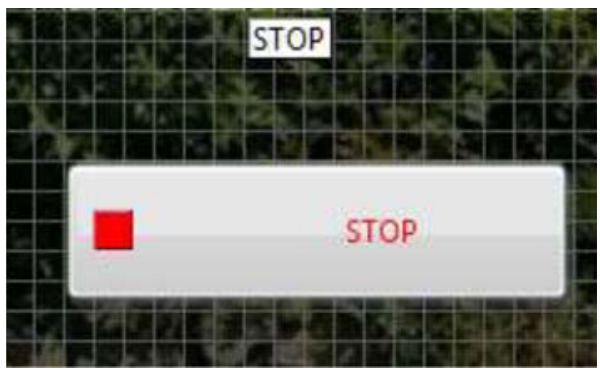

Fig. 9. The STOP button
The STOP button can be pressed as well to stop the LabVIEW solar program. The STOP button image is shown in Fig. 9:

Following input has been added to the LabVIEW program. The input once added will generate the corresponding output and graphs. The analysis using solar LabVIEW project can help in the further analysis and can be used to obtain the optimized results.

\section{Results}

To an actual decent estimate, the cell current is related as the direct proportional relation to the cell irradiance. Therefore, if the cell current is recognized under normal test conditions as $G_{0}=1 \mathrm{~kW} / \mathrm{m}^{2}$, the cell current at any other irradiance, $G$, is given by

$$
I_{l}(G)=\left(G / G_{0}\right) \cdot I_{l}\left(G_{0}\right) .
$$

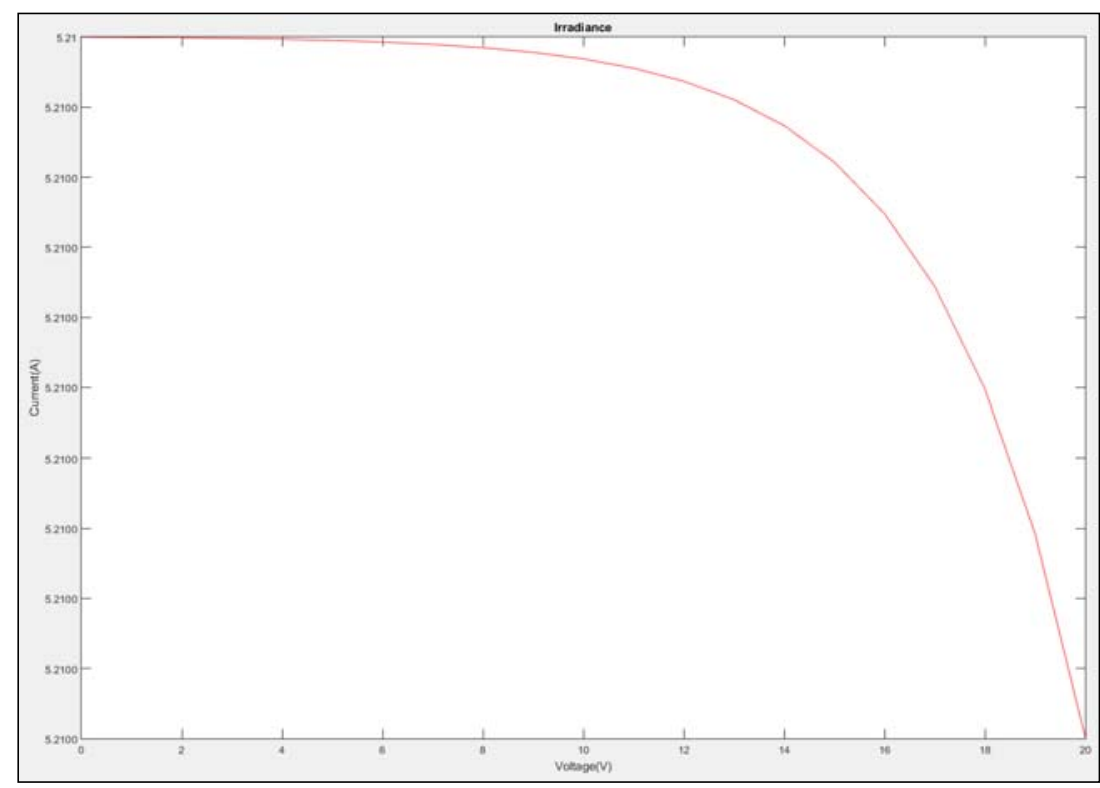

Fig. 10. IV characteristics of non-ideal PV-cell (MATLAB) 


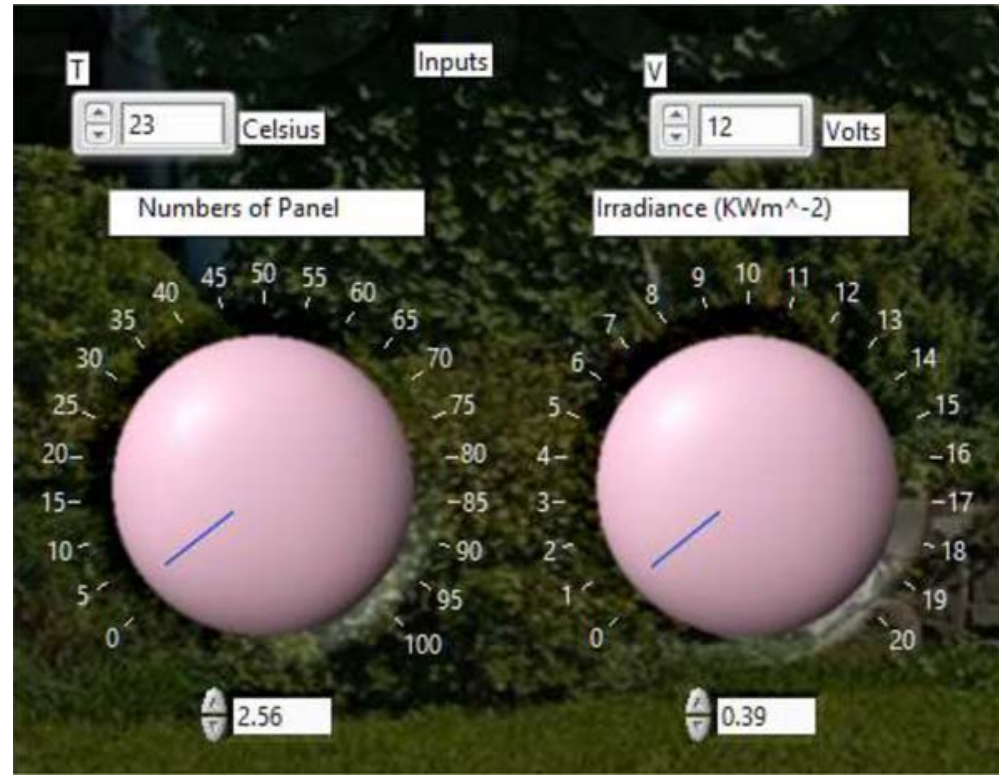

Fig. 11. Input settings

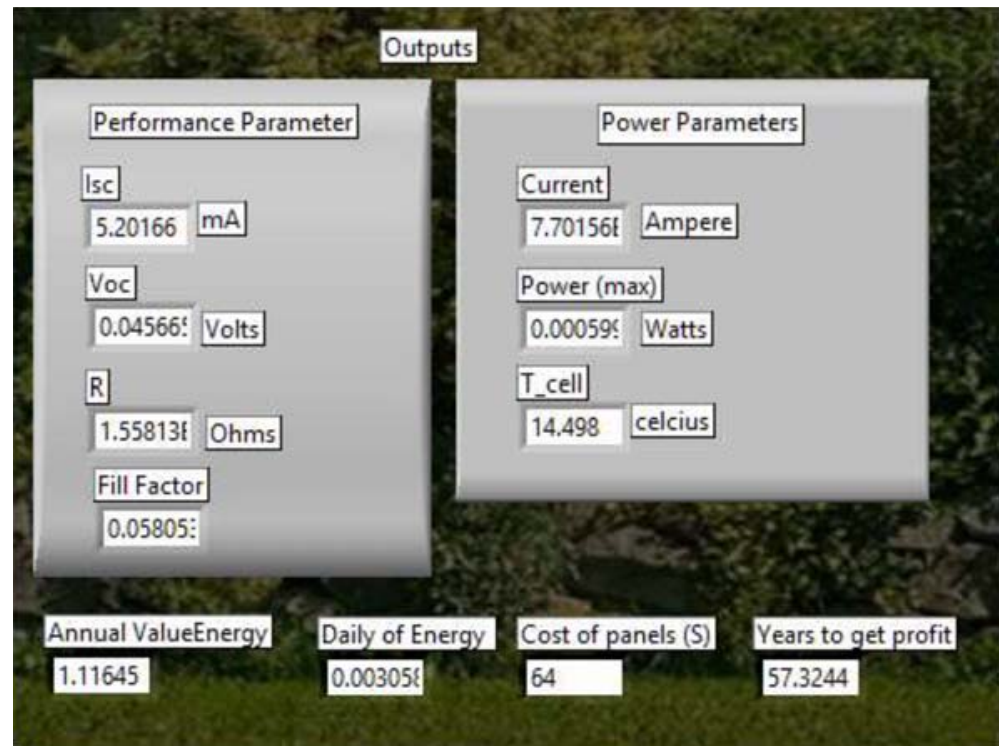

Fig. 12. Output settings

The IV characteristics of the PV-cell are shown below in Fig. 10.

In Fig. 11, the input has been set to some specific points. Since there are four inputs namely initial temperature, voltage, number of panels and irradiance. The initial temperature has been set to $23{ }^{\circ} \mathrm{C}$, desired voltage is $12 \mathrm{~V}$, the number of panels to between 2 and 3 and irradiance to $1 \mathrm{KWm}^{-2}$. Setting the parameters to those numbers will result in the corresponding output calculated parameters and graphs.

By setting the input parameters in Fig. 11, the calculated output comes out to be in Fig. 12. Figure 12 shows the result.

The parameters shown in Fig. 12 are due to input settings in Fig. 11. The performance parameters include short circuit current, Open circuit voltage, internal resistance, fill factor having values $4.699 \mathrm{~mA}$, $0.04566 \mathrm{~V}, 2.77 \mathrm{ohms}$ and 0.058 whereas the power parameters include current, max power and cell temperature having values $4.23 \mathrm{~A}, 0.0005 \mathrm{~W}$ and 286.417 Kelvin while the other factors including annual value energy, daily energy, cost of panel and years to get profit have values $17.437 \mathrm{~J}, 0.0477 \mathrm{~J}, 736.906 \mathrm{USD}$ and 42.261, respectively. For inputs other than set in Fig. 15, the output will come accordingly and vice versa.

Figures 13 and 14 represent the solar power generated vs number of panels and solar generated power on daily basis vs number of the panels. It can be seen that the graph is not a straight line. The graph takes 


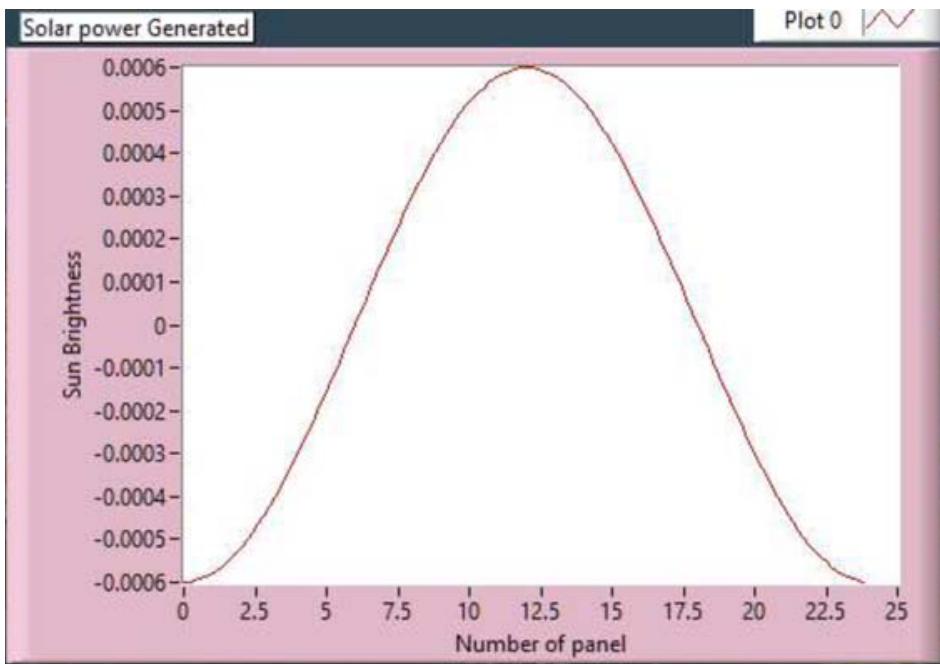

Fig. 13. Output graphs

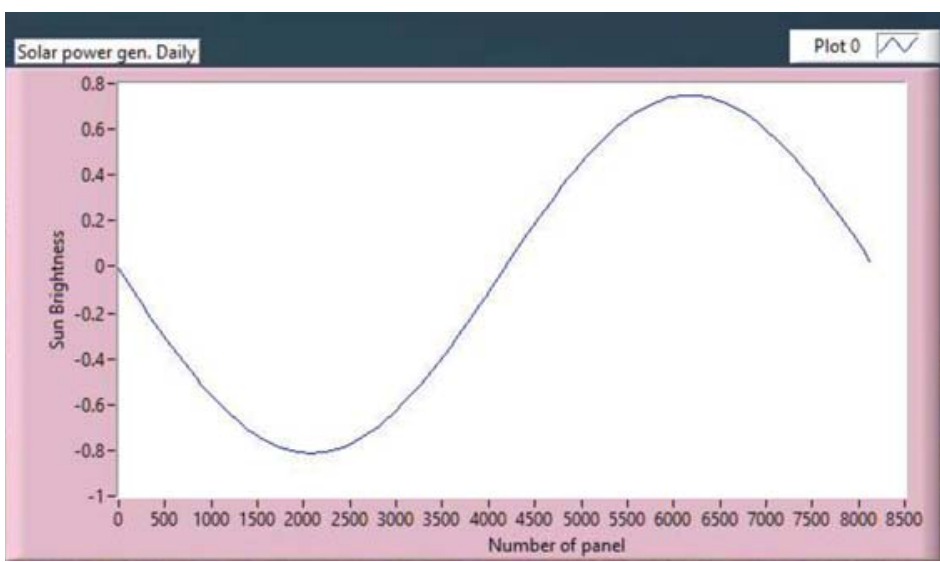

Fig. 14. Output graphs

input values and computes the corresponding outputs. The input values can be used to change the corresponding curve shape, but the curve is always a part of sinusoid since it can be seen that the power does vary with the number of the panels, therefore it results in a sinusoidal curve. Figure 15 shows the result of the complete screen while the LabVIEW program is running. The complete program displays the quantities that are explained in the Results section.

The complete LabVIEW program can be used to calculate and estimate the solar results and the running solar project has been shown in Fig. 15.

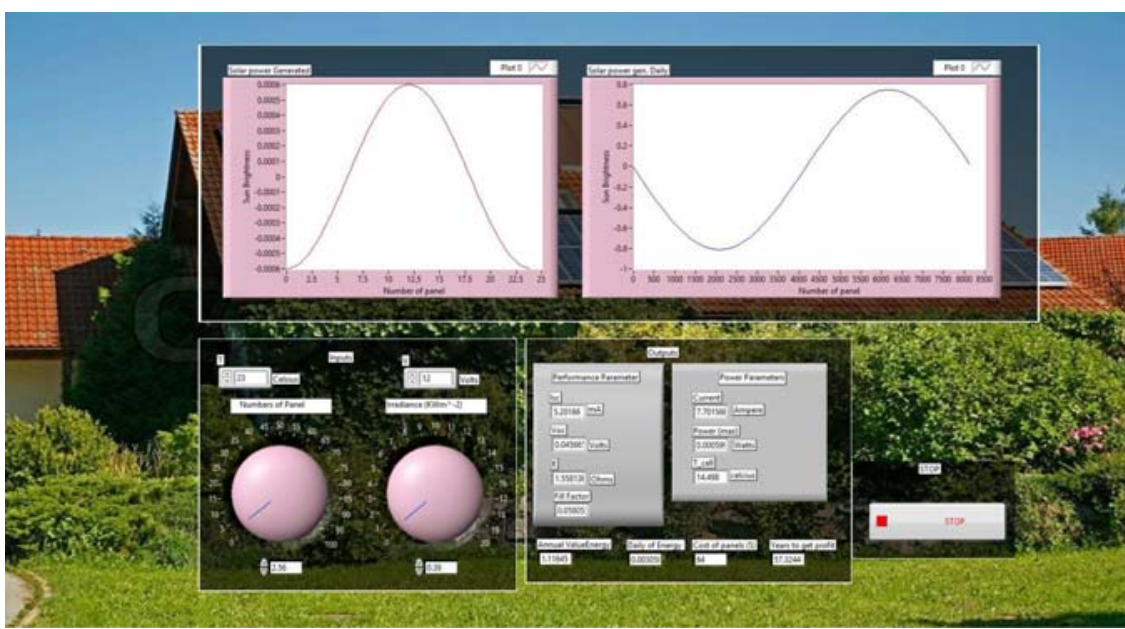

Fig. 15. Complete LabVIEW program in running condition 


\section{Conclusions}

In countries such as in Middle East and specific areas in Sindh district in Pakistan there is more heat than in other parts of the world and these areas do not have a specific steady low temperature for the most part of the year. These areas can be the hub of the solar energy and there will no longer be a need for the natural resources. So, the idea of this research work is to study the VI characteristics of the solar panel using LabVIEW. The solar simulation analysis has been implemented in LabVIEW. LabVIEW is being used as it has several features that help in designing the Graphical interface structure-based simulation [38]. LabVIEW is a tool preliminarily designed for this purpose. Mathematical equations representing the solar system have been first explained with details and then implemented in LabVIEW. After creating the simulation interface with LabVIEW, the system is differentiated with respect to input and output parameters. The input and output parameters have been correctly displayed and detailed. After that some input parameters have been applied and details recorded. As designed, the system takes the input parameters and produces the corresponding output graphs and output parameters.

VI characteristics of the solar panel help in studying the analysis and operating temperature conditions. The obtained results help in selecting the optimal conditions, situation and location to install the solar power grid. Likewise, the safe conditions can be determined. The simulation can be further improved by adding more analytical equations. Addition of datalogger helps in recording the previous data (history) and the simulation can then be classified as the casual simulation (one that stores the previous results and the future decision includes considering the history). Adding the datalogger keeps track of the data and simulation can be performed for 10 years or longer to determine the life of the system (warranty status). There are lots of other factors like system converted efficiency, life span, warranty, working probability analysis can be performed in LabVIEW by implementing the equations corresponding to it. There are certain uncertainties in the Solar system that are required to be calculated. These uncertainties include system failure ratio and working in the case when there is no sunlight for a few days.

Solar energy is efficient for generating electrical electricity as compared to the traditional sources that will run out sometime. An efficient system requires pre-installed testing and calculations which are discussed in this paper by creating a LabVIEW for it. Generating energy from solar system is a great trend. Solar energy projects contribute more towards creating the jobs and now it is one of the fastest growing industries in the United States of America [39].

\section{References}

[4] Spanias A. S. (2017), Solar energy management as an Internet of Things (IoT) application. In: 8th International Conference on Information, Intelligence, Systems \& Applications (IISA), Larnaca, Cyprus, pp. 1-4.

[5] Hollingum J. (2001), Solar energy conversion. Sensor Review, 21(2).

[6] Kumar Pathania A., Goyal B., Raj Saini J. (2017), Diffusion of adoption of solar energy - a structural model analysis. Smart and Sustainable Built Environment, 6(2), 66-83.

[7] Ishay J. S., Rosenzweig E., Litinetsky L., Kirshboim S. (2000), The solar cell in hornet cuticle: nanometer to micrometer scale. Microscopy, 49(4), 559-568.

[8] Arefifar S. A., Ordonez M., Mohamed Y. (2017), Energy management in multi-microgrid systems - development and assessment. In: IEEE Power \& Energy Society General Meeting, Chicago, IL, p. 1.

[9] (1998), Labview Graphical Programming (2nd edition). Industrial Robot: An International Journal, 25(3).

[10] (2002), National Instruments LabVIEW-based distributed $\mathrm{I} / \mathrm{O}$ system delivers intelligent networked measurement and control. Sensor Review, 22(1).

[11] Haokip S. G. T., Shah G., Lahiri U. (2017), Psycho-physiological implications of computer based social and non-social interactive tasks for children with autism. In: 8th International Conference on Computing, Communication and Networking Technologies (ICCCNT), Delhi, pp. 1-7.

[12] Sharma P., Duttagupta S. P., Agarwal V. (2009), Characterization and modeling of flexible photovoltaic modules for portable power applications. In: International Conference on Sustainable Power Generation and Supply, Nanjing, pp. 1-7.

[13] Farooq A., Zahid A. (2018), SCADA Based Control of Plant CS40000 Advanced Process Laboratorial Equipment. International Journal of Trend in Research and Development (IJTRD), 5(2), ISSN: 2394-9333.

[14] Farooq A., Alhalabi W., Alahmadi S. M. (2017), Traffic systems in smart cities using LabVIEW. Journal of Science and Technology Policy Management.

[15] Procel P., Ingenito A., De Rose R., Pierro S., Crupi F., Lanuzza M., Cocorullo G., Isabella O., Zeman M. (2017), Opto-electrical modelling and optimization study of a novel IBC c-Si solar cell. Prog. Photovolt: Res. Appl., 25, 452-469.

[16] Ammous M., Fendri D., Chaabene M. (2017), Dynamic modeling and LabVIEW simulation of a photovoltaic thermal collector. In: 8th International Renewable Energy Congress (IREC), Amman, pp. 1-6.

[17] Rafael da Silva M. (2016), Modeling of a fuel cell with PI controller in Simulink - Matlab. In: 3rd International Conference on Systems and Informatics (ICSAI), Shanghai, pp. 160-165.

[18] Masters G. M. (2005), Photovoltaic Systems. In: Renewable and Efficient Electric Power Systems, Masters G. M. (ed.)

[19] van der Ham A. J., Roes M. G. L. (2017), A distributed maximum power point tracking system for solar electric vehicles. In: 19th European Conference on Power Elec- 
tronics and Applications (EPE'17 ECCE Europe), Warsaw, pp. P.1-P.10.

[20] Basu T. S., Maiti S., Chakraborty C. (2016), A hybrid modular multilevel converter for solar power integration. In: IEEE 7th Power India International Conference (PIICON), Bikaner, pp. 1-6.

[21] Singh A. K., Hussain I., Singh B. (2016), An improved P\&O MPPT algorithm for single stage three-phase grid integrated solar PV system. In: IEEE 7th Power India International Conference (PIICON), Bikaner, pp. 1-6.

[22] Yusof M. F. M., Yusof N. S., Ahmad A. Z. (2017), An analytical strategy for energy storage sizing in isolated microgrid with PV source. In: IEEE Conference on Systems, Process and Control (ICSPC), Malaysia, pp. 122-127.

[23] Datta S. K., Bonnet C., Nikaein N. (2014), Personalized power saving profiles generation analyzing smart device usage patterns. In: 7th IFIP Wireless and Mobile Networking Conference (WMNC), Vilamoura, pp. 1-8.

[24] Colak I., Demirtas M., Kabalci E. (2014), Design, optimisation and application of a resonant DC link inverter for solar energy systems. International Journal for Computation and Mathematics in Electrical and Electronic Engineering, 33(5), 1761-1776.

[25] Raja Mohamed S., Jeyanthy P. A., Devaraj D. (2017), Investigation on the impact of high-penetration of PV generation on transient stability. In: IEEE International Conference on Intelligent Techniques in Control, Optimization and Signal Processing (INCOS), Srivilliputhur, pp. 1-6.

[26] Alessandro V., Di Napoli F., Guerriero P., Daliento S. (2014), A novel circuit model of PV cell for electrothermal simulations. In: IET Conference Proceedings, p. 7.3.4.

[27] Bhagavathy S., Pearsall N., Putrus G., Walker S. (2017), Performance assessment of a three-phase distribution network with multiple residential single-phase PV systems. CIRED - Open Access Proceedings Journal, 2017(1), pp. 2480-2483.

[28] Katiraei F., Mauch K., Dignard-Bailey L. (2007), Integration of photovoltaic power systems in high-penetration clusters for distribution networks and mini-grids. Int. J. Distrib. Energy Res., 3(3), 207-223.

[29] Vasanasong E., Spooner E. D. (2000), The prediction of net harmonic currents produced by large numbers of residential PV inverters: Sydney Olympic village case study. In: Proceedings of Ninth International Conference on Harmonics and Quality of Power, IEEE, pp. 116-121.

[30] Luo X., Wang J., Dooner M., Clarke J. (2015), Overview of current development in electrical energy storage technologies and the application potential in power system operation. Applied Energy, 137, 511-536.
[31] Hashemi Toghroljerdi S., Ostergaard J., Yang G. (2013), Effect of reactive power management of PV inverters on need for energy storage. In: 39th IEEE Photovoltaic Specialists Conf.

[32] Lin J. H., et al. (2018), A high-efficiency and fast-transient digital-low-dropout regulator with the burst mode corresponding to the power-saving modes of DC-DC switching converters. In: IEEE International Solid - State Circuits Conference - (ISSCC), San Francisco, CA, USA, pp. 314-316.

[33] Kuitche J. M., Pan R., Tamizh Mani G., (2012), Statistical analysis of back surface vs. cell temperatures of c-Si modules using measurement error models. In: 38th IEEE Photovoltaic Specialists Conference, Austin, TX, pp. 002953002956.

[34] Kuitche J., Oh J., Brunger A., Inoue T., Muller M., Bauerdick C., Althaus J., Kiehn S., Feng V., Therhaag U., Struwe R. (2011), One year NOCT round-robin testing per IEC 61215 standard. In: 37th IEEE PVSC, Seatle, WA.

[35] Hasan M. N., Habib M. M., Matin M. A., Amin N. (2017), Modeling of high efficient perovskite-Si tandem solar cell. In: 3rd International Conference on Electrical Information and Communication Technology (EICT), Khulna, pp. 1-5.

[36] Cheng Z., Delahoy A. E., Su Z., Chin K. K. (2014), Steady state minority carrier lifetime and defect level occupation in thin film CdTe solar cells. Thin Solid Films, 558, 391399, ISSN 0040-6090.

[37] Lechene B. P., Clerc R., Arias A. C. (2017), Theoretical analysis and characterization of the energy conversion and storage efficiency of photo-supercapacitors. Solar Energy Materials and Solar Cells, 172, 202-212, ISSN 0927-0248.

[38] Cui Z., Tian Z., Zhang Y., Bi Z., Fu S. (2018), Study on real time 3D imaging of streak tube lidar based on LabVIEW. Optik, 157, 768-773, ISSN 0030-4026.

[39] Tian Z., Cui Z., Zhang L., Xu T., Zhang Y., Fu S. (2014), Control and image processing for streak tube imaging lidar based on VB and MATLAB. Chin. Opt. Lett. 12, 060015.

[40] Inoue Y., Uchiyama M. (2017), Development of PLC system with large capacity and high reliability. CIRED Open Access Proceedings Journal, 2017(1), 1035-1037.

[41] Morris A. S., Langari R. (2012), Data Acquisition with LabVIEW - Chapter 5. In: Measurement and Instrumentation, Butterworth-Heinemann, Boston, 115-133, ISBN 9780123819604

[42] Leaman C. (2015), The benefits of solar energy. Renewable Energy Focus, 16(5-6), 113-115, ISSN 1755-0084. 